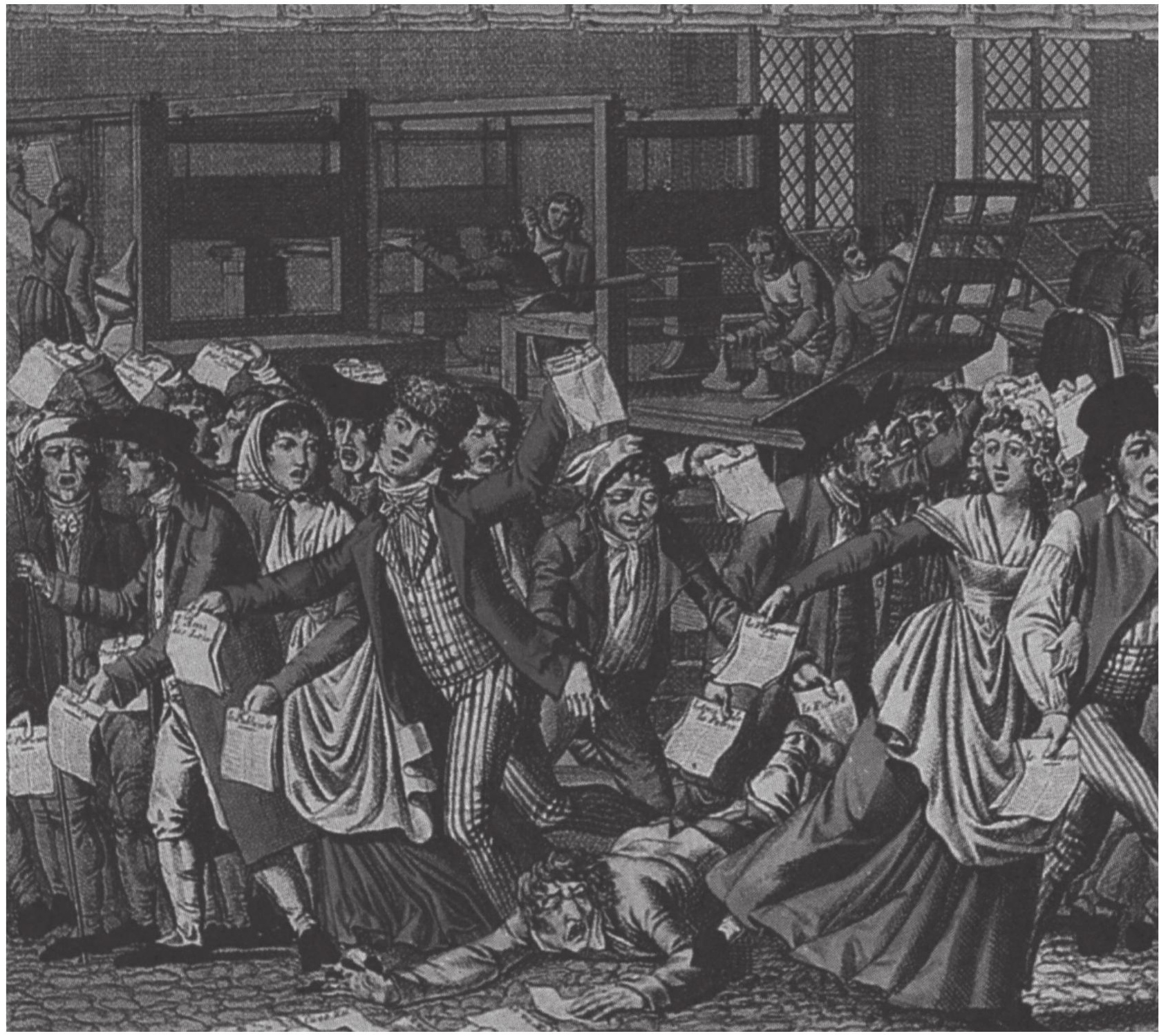

Liberdade de Imprensa, | 797

\title{
LEÃO SERVA
}

é jornalista e autor

de A Batalha de Sarajevo

(Scritta) 

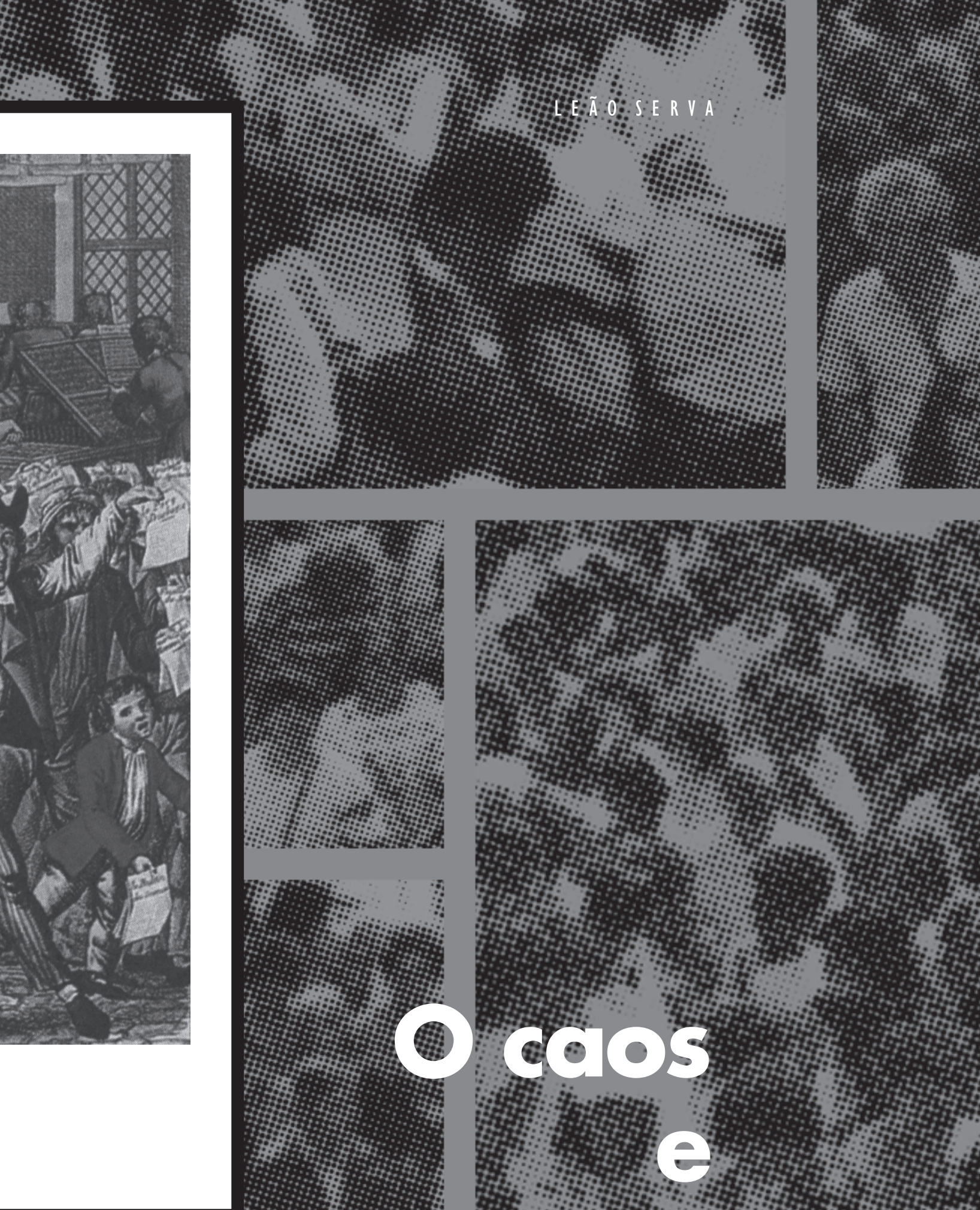

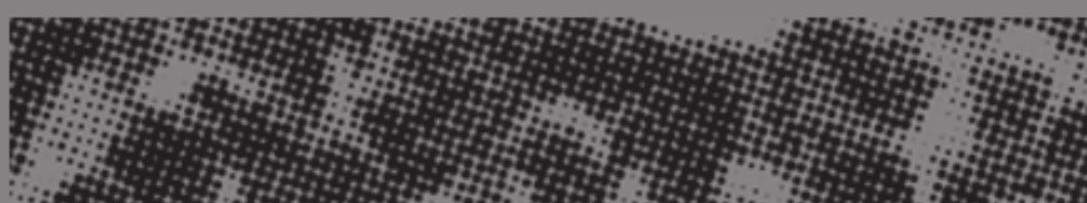

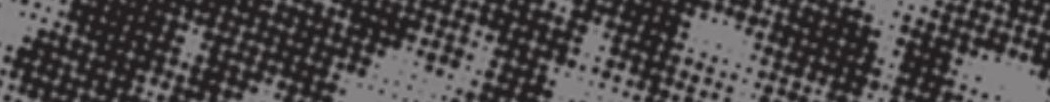

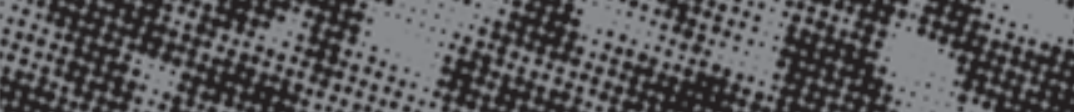

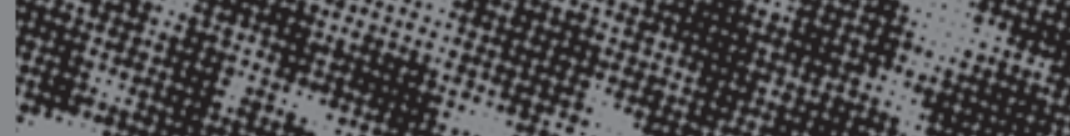

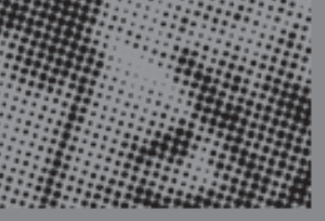

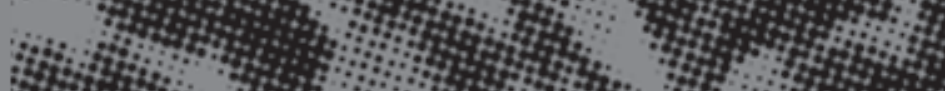

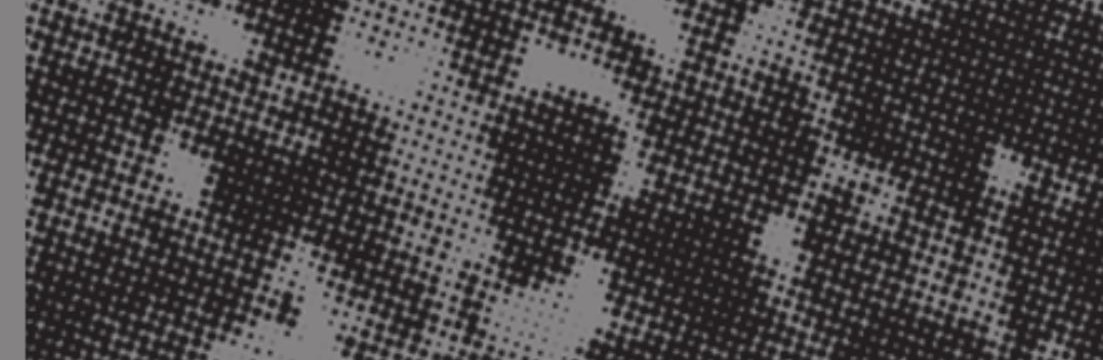

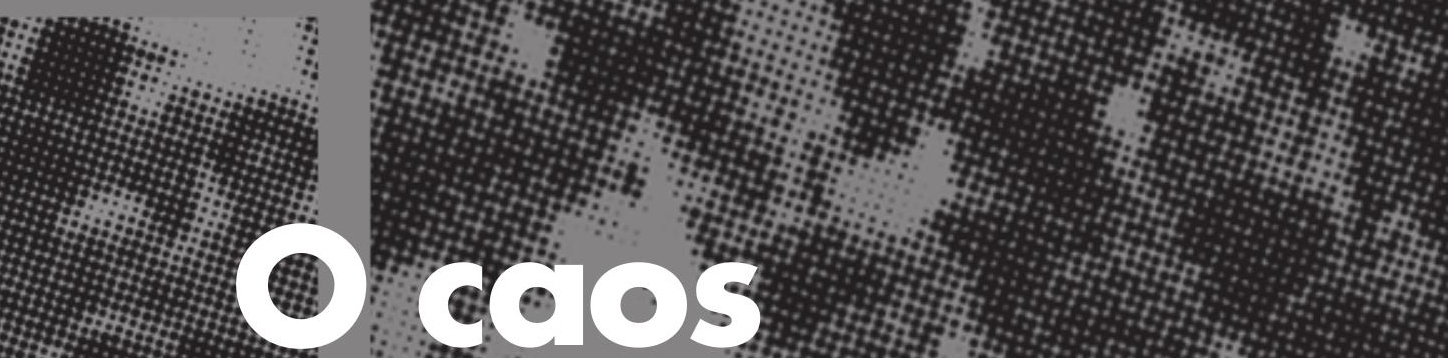

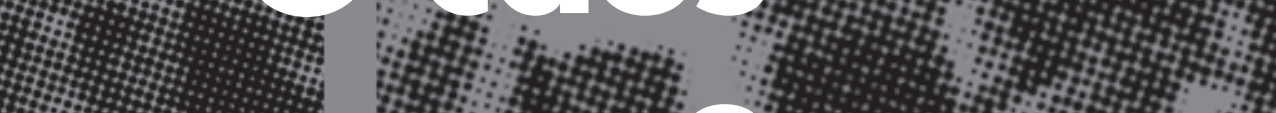
mom

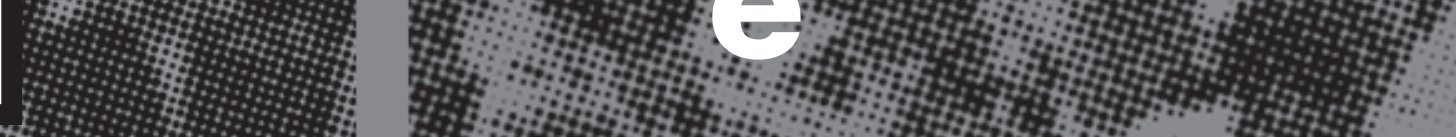

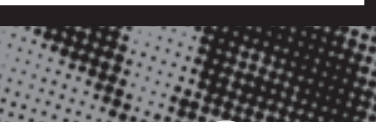

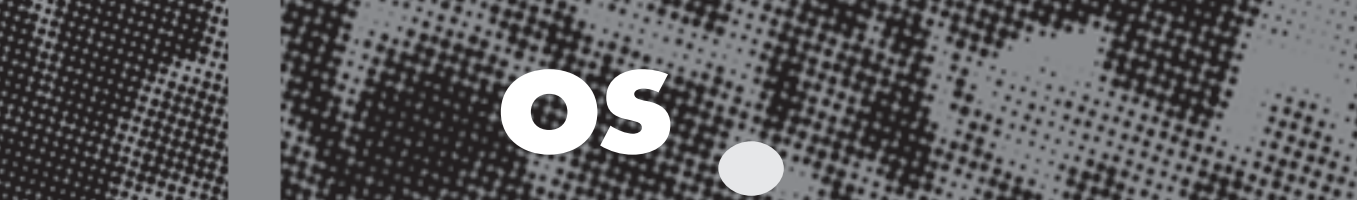

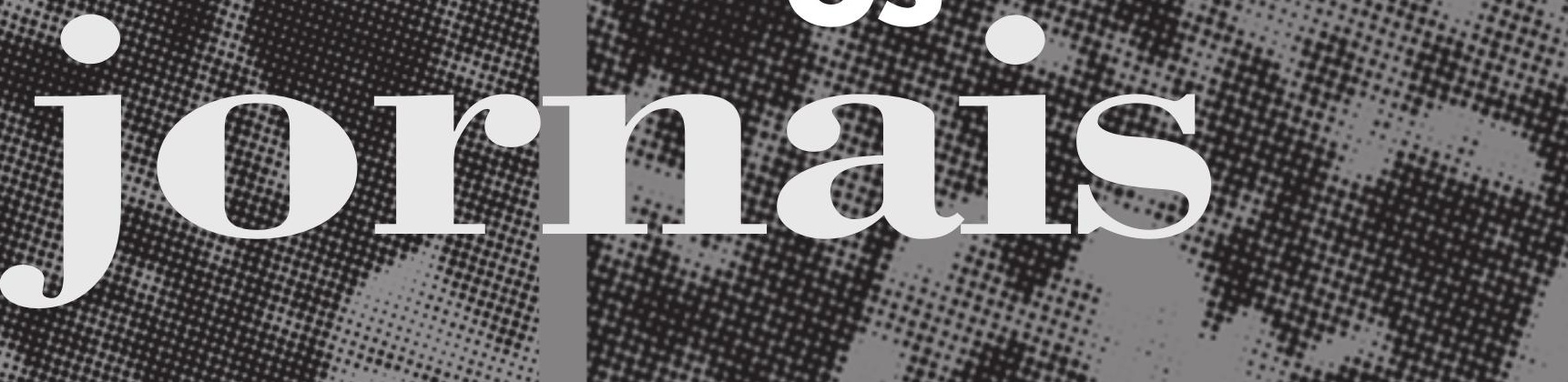

H.

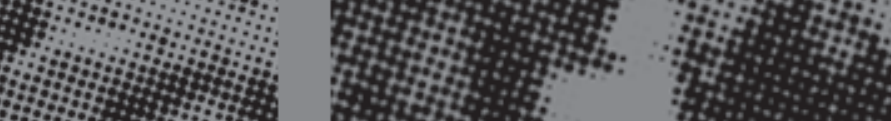


identidade nacional tem sido um tema de preocupação constante das ciências sociais e políticas no Brasil, em grande medida por sua aparente recusa em se revelar pelas mesmas formas que caracterizam as dos outros países. Possivelmente se pode afirmar que uma característica fundamental da alma brasileira em relação à de outros povos é a ausência de uma identidade política nacional e essa essência pode ter parte fundamental na coesão nacional que tem marcado a história deste último império da geopolítica colonial. Assim, a essência brasileira talvez seja a falta de um elemento de identificação do ser nacional, ao menos no estilo das manifestações que marcam a identidade de outros povos.

Elemento fundamental na composição da ideologia contemporânea, neste período marcado pela eliminação progressiva de outros componentes que a cimentavam, o conjunto dos meios de informação no Brasil opera a perpetuação quotidiana de nossa tão característica não-identidade nacional. Há algumas qualidades em nossa imprensa que se relacionam com isso e ao mesmo tempo catalisam o processo de não-reconhecimento de um sentido comum entre os habitantes do país.

Exemplo de uma dessas qualidades do jornalismo brasileiro: o cosmopolitismo da cobertura cultural, reflexo dos interesses da elite que sustenta sozinha o sistema de informação - dando ao país essa característica fundamental, que é o fato de os jornais voltados para a menor parcela da população, a burguesia, serem os campeões de circulação, batendo os jornais chamados populares, o que é um contra-senso estatístico e econômico mas consoante com a identidade nacional. Se a elite ouve com mais interesse Satie do que Villa-Lobos ou Frank Sinatra do que Roberto Carlos, Madonna em vez de Marina Lima, é natural que a cobertura cultural dos jornais traga as notícias sobre fatos estrangeiros com mais destaque do que as ocorrências locais.

O mesmo se pode dizer do noticiário sobre fatos internacionais. Embora dedique uma atenção desproporcional à políti- ca dos países europeus e dos Estados Unidos - pólos propulsores do capitalismo internacional -, o conjunto da cobertura internacional na imprensa brasileira é superior ao conjunto da cobertura internacional dos jornais do exterior, mesmo ou ainda mais que os daquelas metrópoles do capitalismo contemporâneo. Como resultado, o brasileiro que lê jornais tem condições de saber melhor o que ocorre no mundo do que o leitor americano ou inglês, e por isso consegue entender melhor os fatos ocorridos fora. Certamente o leitor brasileiro tem em seus jornais mais elementos para entender os personagens e os resultados de uma eleição americana do que um leitor americano de jornais para entender fatos semelhantes ocorridos no Brasil ou mesmo na França.

Ao mesmo tempo, essas características têm papel considerável na composição da não-identidade brasileira. Qual é, afinal, a identidade cultural que transparece de nossas páginas culturais? Qual é a identidade que se depreende do processo de escolha de notícias que dá mais destaque a fatos ocorridos na Inglaterra do que em Minas Gerais; ou que só admite como heróis nacionais os que são apontados por eleição de instituições estrangeiras - para lembrar o caso de Chico Mendes, “descoberto" pelo Brasil quando premiado nos Estados Unidos?

O processo mesmo de edição em jornal pode explicar em parte esses procedimentos que induzem à confusão em vez de esclarecer o sentido da informação. No texto que se segue - baseado em palestra apresentada no $3^{\circ}$ Congresso Internacional Latino-americano de Semiótica, em setembro de 1996, sob o nome de "O Caos na Imprensa" - procurei mostrar como a imprensa produz uma visão necessariamente confusa da realidade enquanto ideologicamente alega que seu objetivo é a compreensão dos fatos.

\section{A IMPRENSA E O CAOS}

Existe uma piada tradicional entre jornalistas, sempre apresentada como uma 
história verdadeira, que eu gostaria de contar. Ao comentar um certo episódio ligado ao noticiário policial, um repórter mais experiente narra ao seu colega, recém-iniciado na carreira, a triste experiência ocorrida com Fulano de Tal. Certa feita o personagem foi assaltado por um ladrão à luz do dia, no centro da cidade, e perdeu a carteira e até mesmo o carro. Poucos dias depois, o ladrão é preso e Fulano convocado para o reconhecimento. Ao deixar a delegacia, Fulano é entrevistado por uns repórteres e sua foto publicada em jornal.

Passam alguns meses, Fulano entra em uma loja e ao chegar ao caixa é tratado com grande frieza. Depois de alguns minutos, o gerente pergunta: “O sr. não esteve envolvido em um assalto um tempo atrás?”.

Casos de leitores atentos de imprensa que confundem informações que parecem simples a quem conhece a "história verdadeira" são quase tão comuns quanto casos de leitores que entendem a história mais ou menos como o autor ou uma testemunha do fato. Confusões tão comuns sugerem que devemos nos perguntar se não se trata de uma característica sistemática dos meios de comunicação, dessas características que a norma procura desqualificar como exceção mas que no entanto são parte da própria regra. Um caso semelhante à própria existência do crime, característica essencial da nossa e de todas as sociedades, mas sempre apontada como uma distorção episódica da natureza, uma exceção à profunda honestidade do ser humano.

\section{- CAOS É O TEMA FUNDAMENTAL DA IMPRENSA}

Vou tentar explicar a razão pela qual o procedimento mesmo da imprensa gera esses enganos e não a desatenção ou inexperiência do leitor.

A imprensa trabalha necessariamente sobre o caos. Sua matéria-prima é o próprio caos, o caldo amorfo que serve de cultura para a confusão e o inesperado, o inusitado, o inculto, etc. As ocorrências imprevistas são o produto surpreendente que deve ser noticiado, segundo todos os preceitos tradicionais - são elas, afinal, que chamam a atenção do homem, e já chamavam mesmo antes da existência da imprensa.

Assim, a surpresa que deve ser componente essencial da notícia pode ser compreendida como o resultado do aspecto non sense do fato noticioso, ou seja: algo só faz sentido quando é de conhecimento prévio de quem testemunha, necessariamente se harmoniza ou coaduna com um signo referencial interior. O que surpreende, então, necessariamente não faz sentido - ao menos até que a ação comunicativa (jornalística ou não) "explique" o fato ou o torne conhecido e assim crie a referência interior para o receptor, dê a ele o conhecimento necessário para que os fatos passem a "fazer sentido".

Para reforçar essa vocação surpreendente da notícia, há inúmeros ditos populares que ressaltam a disposição da mídia por revelar o que sai da norma. (O uso recorrente de ditados ou piadas para transmitir os procedimentos jornalísticos é uma das formas de pedagogia ou iniciação na prática da carreira, pois se trata de uma profissão que por não ser baseada em técnicas consagradas pela ciência acaba se transmitindo de forma assistemática.) Dizem alguns desses ditados: "No news is good news" (a ausência de notícias é uma boa notícia), dizem os ingleses, implicitamente ressaltando o que diz um outro ditado, este mais usado por jornalistas - "Good news is no news" (ou seja, boa notícia não é uma notícia). Há também um ditado brasileiro, mais irreverente: "Se um cachorro morde um homem, não há notícia, se o homem morde o cachorro, isso é notícia".

Nos dois casos, o procedimento jornalístico justificado e resumido nesses ditos é o de destacar e noticiar o raro, o paradoxo, o imprevisto - o caos, aparente ou verdadeiro. É isso que caracteriza a NOTÍCIA, matéria-prima dos meios de comunicação, dos quais o jornal é o avô mas também a mais perfeita tradução.

Para manter-nos circulando em torno da metáfora da violência urbana, podemos dizer que o que faz de um crime notícia é 
exatamente o seu elemento surpreendente: o bandido é inesperado, sua estratégia não faz sentido, chega quando ninguém espera, provoca uma reação assustada e atenta, aparece a pé quando o fluxo da classe média se dá dentro de carros paralisados pelo congestionamento. A pé ele se desloca para fugir a uma velocidade que os modernos automóveis não alcançam. Ele engana, sai da norma, surpreende, surge e desaparece em um piscar de olhos e acima de tudo pode matar uma pessoa como quem mata moscas. A notícia é uma bandida, que rouba espaços das "boas novas", dos fatos previstos e repetidos da rotina, uma informação que se afirma pela velocidade inesperada (lembremse que também aqui “a má notícia cruza os céus como um relâmpago”). Mesmo quando os meios de comunicação eram censurados, notícias importantes cruzavam as cidades em velocidade de Internet.

\section{A IMPRENSA CONSIDERA SUA MISSÃO ORGANIZAR O CAOS}

Ao mesmo tempo que tira do caos a sua matéria-prima, a imprensa procura organizá-lo, ordená-lo, dispor as notícias que emergem da geléia geral em um plano organizado, hierarquizado, categorizado: o caos se harmoniza, se "civiliza" nas páginas de jornal ou no noticiário da TV, nas páginas da Internet ou no rádio. A isso se chama "edição", a organização das informações conforme as regras do meio e do veículo específico e conforme a lógica do grupo incumbido do trabalho de editar, conforme a compreensão que ele tem dos fatos e o que ele supõe ser o interesse e a capacidade de entendimento de seu receptor. Essas regras e os procedimentos de organização das notícias no espaço do jornal são o roteiro de uma ação que pretende DETER os fatos, obter sua essência, mais do que explicá-los, conhecer ou ao menos parecer explicá-los.

O sentido desse verbo "deter" é muito feliz para o papel ambíguo que os meios de comunicação procuram exercer sobre a massa amorfa e crua de fatos que eles publicam. Deter o fato para que ele não passe, que permaneça "vivo" aos olhos do leitor até a expiração do jornal; deter no sentido de saber explicá-lo, de colocá-lo sob uma perspectiva compreensível para o leitor, de criar o signo referencial interior que permita sua compreensão. Deter portanto significa organizar as notícias, quase como submetê-las, recuperá-las. Submetê-las à ordem, leia-se, às categorias jornalísticas. Recuperá-las no sentido de alcançar novamente algo que fugia, pois o tempo não pára e o acontecimento mesmo se foi; então é preciso recuperar a capacidade de contá-lo com tantos detalhes que ele se torne um espelho da notícia. Recuperá-las também como forma de dar novamente ao leitor, de início surpreso e incapaz de entender a notícia, capacidade de compreendê-la.

Então notem como essas palavras que se adequam tão bem para explicar a natureza do procedimento jornalístico são também tão recorrentes no jargão do noticiário policial: deter, detenção; recuperar ou reabilitar; submeter ou submissão.

O resultado da edição é uma página organizada, com os fatos hierarquizados conforme a intuição dos editores, o potencial surpreendente dos fatos ou "o desejo dos leitores", como diz a tradição norteamericana de análise do jornalismo. A soma de várias páginas é um jornal ou revista completa, chamada também "edição".

No processo de edição, as notícias são catalogadas taxionomicamente, divididas conforme sua natureza em categorias como "política", "economia", "internacional", “geral”, “cidade", “variedades", “esportes", “cultura”, etc. Cada fato que ocorre e cujo conhecimento é dado à equipe de edição terá que ser classificado conforme uma ou várias categorias mais ou menos como essas. Há sempre problemas que serão dirimidos da mesma maneira como são criadas essas categorias: pelo "bom senso" da equipe ou de sua hierarquia. São notícias como uma ida do presidente da República ao teatro: pode ser "política", por se tratar do presidente; "cultura", por se tratar de teatro. Ou, então, uma notícia sobre o cresci- 
mento do mercado de filmes nos Estados Unidos, pode ser “internacional”, por ocorrer além das fronteiras do Brasil; pode ser “economia", por tratar de um fluxo mercantil, de compra e venda de tíquetes para cinema; e, por fim, pode ser “cultura”, por se tratar de um meio de comunicação normalmente associado à produção artística. Cada uma dessas categorias tem um espaço determinado dentro do conjunto da edição, correspondendo a um pedaço de página, uma página ou várias delas. Assim, a decisão sobre "onde pôr" uma história corresponde a pensar em que lugar do espaço do jornal e também com que outras notícias associar - o que também é uma informação em si.

Ao procurar deter a notícia numa dessas categorias, o editor de um jornal está prendendo a notícia dentro de um "pavilhão" jornalístico, mais ou menos como o diretor do presídio classifica ou organiza cada um dos seus bandidos.

Depois dessa escolha genérica, caberá à edição de cada seção ou pavilhão estabelecer a importância do tal fato em relação aos outros fatos narrados na seção ou página específica. A notícia vai encontrar seu lugar exato no espaço como um preso encontra seu espaço e posição dentro da cela.

Ao final, a notícia será “editada”, detida, em colunas de texto separadas entre si por canaletes de branco exatamente como se fossem grades brancas de uma cela escura. Pronto! o jornal digeriu o fato, organizou, civilizou sua vocação selvagem, imprevisível. Os fios que separavam as colunas de jornal, hoje normalmente substituídos porcanaletes brancos, são como eixos para organização dos conteúdos de cada coluna. Ao mesmo tempo, aqueles fatos ali contidos estão aprisionados: são feras enjauladas em colunas de texto, em páginas de jornal, são elementos do mundo real e "natural" (a natureza sempre entendida como o inverso de civilização), submetidos, subjugados à ordem, domados, pois já não são capazes de surpreender, matar, machucar fisicamente. A descrição jornalística dos fatos não tem o impacto sobre a carne que o fato em si tem.
- CAOS ESTÁ DOS DOIS LADOS DO ESPELHO

Rigorosamente, a imprensa neste momento procura se comportar como os deuses: diante do caos primordial, ela organiza! Aos editores, como aos deuses, nada é caótico, tudo faz parte de um plano anterior, todos os fatos cabem, portanto, em um enredo pré-traçado; são páginas de um romance cujo enredo nós leitores desconhecemos mas os autores, como os próprios deuses, conhecem ou podem explicar.

É assim que se comportam os jornalistas, ou os jornais, já que o rito ultrapassa a ação de cada um de seus atores. Os fatos então devem ser amoldados, arrumados, organizados, conforme um plano maior que nesse caso não é da Criação (dos fatos), mas da representação, reprodução.

O objetivo por trás desses procedimentos todos é o de pôr sob a luz, fazer compreender o fato até então matéria bruta, como vimos. A organização do jornal reflete uma concepção positivista do mundo, que atribui sentidos a tudo. Assim, a edição torna inteligíveis todos os fatos do mundo. Ou pelo menos "engaveta-os" em paradigmas que transmitem a impressão de que tudo vai bem e em ordem.

No entanto, não é isso que acontece. O rito jornalístico que compreende também a proliferação de notícias e informações em cada uma delas, todas empacotadas como sardinhas em lata ou como detentos de uma prisão superlotada, imprime um plano jornalístico para pôr o fato em suas páginas - mas nem por isso o leitor termina por deter a sua essência, o plano geral, a essência do fato narrado.

Um exemplo claro dessa incapacidade essencial dos jornais, que se esconde por trás de uma aparente organização (como se fosse um mundo de formas essencialmente vazias), é dado pelo escritor britânico Lawrence Norfolk, em um texto escrito ainda no começo da guerra civil da BósniaHerzegóvina ("A Bosnian Alphabet”, in Granta, 1993 - publicado no número 30 desta Revista USP).

Diante da barreira de informações, que 
de tantas se tornavam todas impenetráveis, ele decide mergulhar na compreensão da guerra fugindo dos meios de comunicação atuais. Vejam o que ele encontra.

No final do século XVIII, um jornal inglês que existe até hoje, mas com outro nome, noticiava uma guerra entre católicos e muçulmanos em uma região do mundo chamada na época de Sérvia ou Croácia, ou, mais precisamente nos limites desses dois países, chamada Herzegóvina. O jornal noticiava que tinham sido encontrados corpos de cristãos mortos por muçulmanos e decapitados. As cabeças não foram encontradas.

No final do século XX, os jornais noticiam com destaque e assombro o surgimento de cabeças de vítimas da guerra civil entre povos cristãos e muçulmanos naquela mesma região do mundo. Norfolk pesquisa nos arquivos do jornal The Times, então Daily Universal Register, e pergunta: serão essas cabeças aquelas que não foram encontradas pelos repórteres da guerra do século XVIII?

Sua imagem é providencial para destacarmos esse paradoxo entre caos e ordem nos meios de comunicação. De alguma forma "o samba do eslavo doido", que muitos de nós, ou talvez todos, sentimos ouvir quando se fala dos problemas étnicos entre poloneses, checos, iugoslavos, bósnios, croatas, chechenos, etc., pode ter feito com que os leitores atuais e não só os bósnios de 1790 ou 1990 tenham PERDIDO AS CABEÇAS. Em verdade, ao dirigir sua edição, ao organizar os fatos, conforme uma regra que atende à lógica da surpresa, os jornais editam as notícias, justapõem os fatos, sem jamais explicá-los ou permitir uma compreensão genuína - que afinal retiraria a surpresa. É como dizer: se os leitores conhecessem a história da Bósnia, talvez soubessem que a guerra é um destino e não se surpreenderiam com as notícias (que soam velhas a quem leu as narrativas de conflitos anteriores). E os jornais não exerceriam sua atratividade.

O estudo do longo curso quando se fala de guerras parece explicar, ou ordenar, um caos que a "ordem" de cada edição de jornal não permite conter. É como se tratássemos de um filme sobre a desordem, o dragão, diria Merlim, em que cada fotograma parece ordenado em si, mas que a visão de toda a trama apresenta um outro sentido, uma ordem completamente diferente ou mesmo nenhum sentido, nenhuma ordem. Por isso, "bons" viram "maus", vítimas surgem como agressores, agressores assumem o papel de vítimas.

Três anos atrás, neste momento do ano, eu estava cobrindo como correspondente internacional a guerra da Iugoslávia, escrevendo diariamente textos para um dos maiores jornais do Brasil. Desde então escrevi um livro sobre o assunto. Constante-

Tratado Elementar

de Impressão,

ou o Manual do

Impressor, de

Antoine-François

Momoro

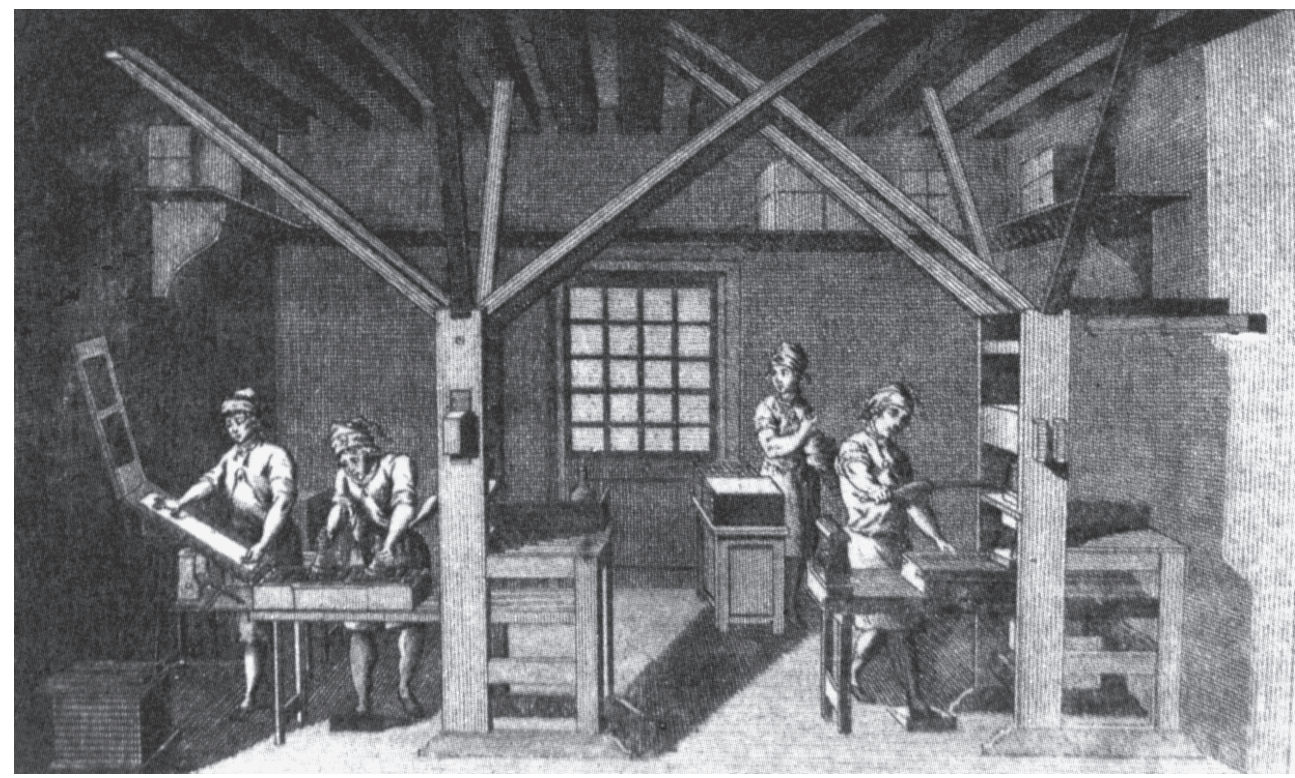


mente aparece alguém que com um sorriso no rosto e um aparente grande nível de conhecimento de meu trabalho me saúda: “Como foi a guerra da Checoslováquia?". Poderia ser Chechênia, Chipre ou qualquer outra parte do estranho mundo "detido" pela mídia internacional.

Essas confusões revelam que a imprensa não organiza o Caos. Muito ao contrário, embora procure ser um espelho organizado e classificado do mundo, a imprensa está sempre gerando confusões na cabeça de leitores, provavelmente exatamente por seu procedimento descrito acima.

Afinal, se dois barcos afundam em locais tão distantes do mundo quanto Londres ou Filipinas, o procedimento jornalístico poderá, muito provavelmente, ser o de dar as duas notícias juntas. Mesmo que um país seja no extremo oposto do mundo em relação ao outro; mesmo que um fato seja atentado e o outro, um acidente, etc.

O leitor vai apreender um pedaço da notícia, provavelmente no caso acima, que dois barcos afundaram. Esquecerá todo o resto, não por despreparo ou inexperiência, mas porque a justaposição, a edição mesma da notícia, pauta-se por critérios jornalísticos, que não são os da história, da natureza, da razão intelectual ou de qualquer outra forma de pensar o mundo.

O fato de o modelo de organização do mundo, no espelho do mundo que a im- prensa pretende ser, não seguir as fórmulas naturais ou mesmo outra qualquer forma intelectual de representação faz com que a compreensão do mundo concedida pela imprensa seja uma compreensão peculiar do mundo, que se esgota em si, ou seja: compreender o mundo pelo modelo da imprensa não significa compreendê-lo de fato, mas compreender o mundo pelo modelo da imprensa. Como olhar uma foto não permite conhecer de fato e genuinamente o objeto fotografado, mas apenas conhecer a representação fotográfica daquele objeto.

A sofisticação do procedimento jornalístico, desde logo com o aumento em progressão geométrica dos tamanhos das edições, bem como o acesso cada vez maior a informações sobre um universo cada vez mais amplo de locais, temas e países, faz com que o volume de informações disponíveis aos leitores seja cada vez maior. E, assim, o caos gerado pelo procedimento de construção do modelo de mundo feito pela imprensa tende a ficar mais claro. Talvez a algum desavisado possa parecer que confusões entre Bósnia e Checoslováquia, ou entre república Checa e Chechênia, ou entre vítimas e criminosos, etc., sejam típicas dos últimos anos. Mas certamente são típicas do estágio atual do mundo, cada vez mais informado apenas pelos meios de informação.

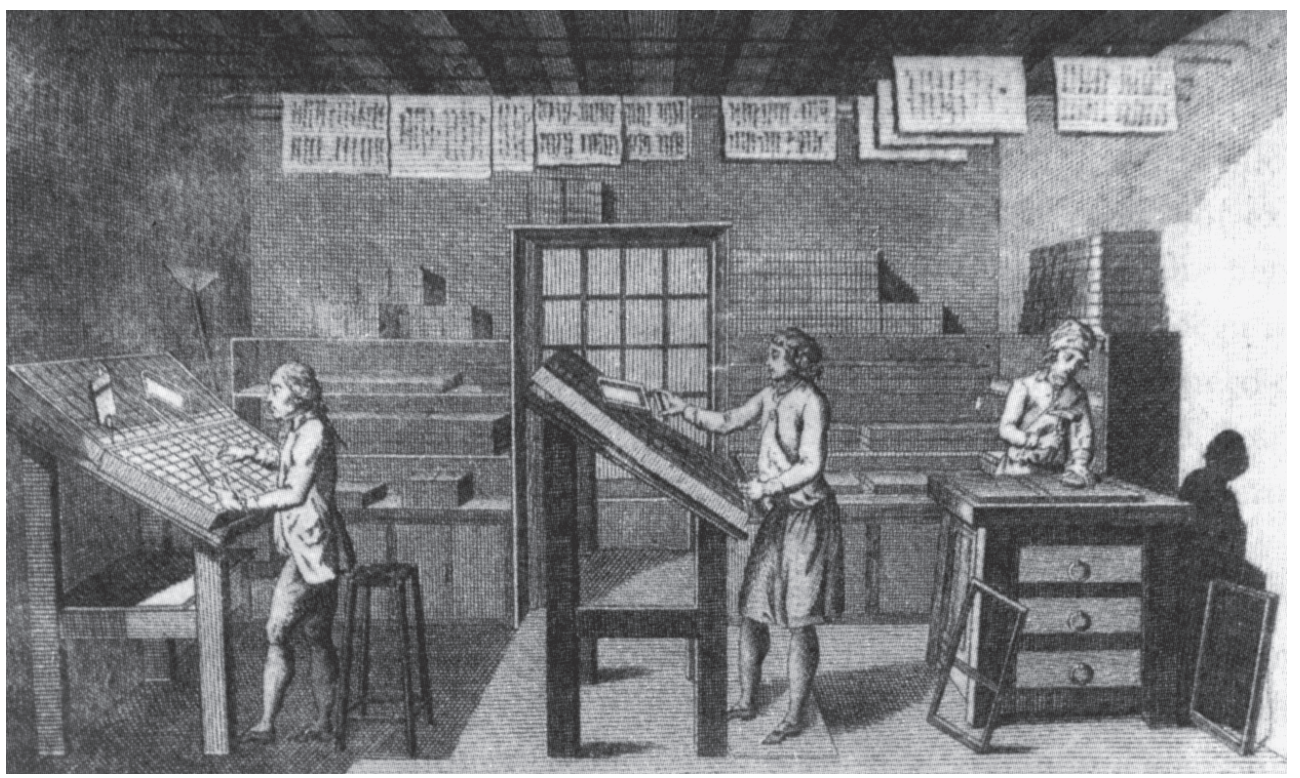

